\title{
THE INCIDENCE OF ECTOPIC BONE FORMATION IN POST- TRAUMATIC PARAPLEGIC PATIENTS OF DIFFERENT RACIAL GROUPS
}

\author{
By A. T. Scher, M.B., Ch.B., D.M.R.D. \\ Spinal Injuries Centre, Conradie Hospital, Cape Town, South Africa
}

Abstract. Analysis of X-rays of 317 traumatic paraplegics and tetraplegics of different racial groups shows that there is no higher incidence of ectopic bone formation in darkskinned patients although there is an increased predisposition for keloid formation in dark-skinned races. There is a higher incidence of ectopic bone formation in complete paraplegics. Patients with stab wounds show lower incidence of this complication.

Key words: Ectopic bone formation, dark-skinned paraplegics, keloid formation, stab wounds.

\section{Introduction}

THE formation of ectopic bone (extra-osseous bone) in the soft tissues is a well recognised complication of paraplegia. This condition was first described in I9I8 and despite considerable documentation and experimental work the aetiology of this condition is still unknown. No specific treatment which will prevent the onset of this condition has been discovered and there is no way of causing its regression apart from surgical removal, once established.

The patients admitted to Spinal Injury Units in South Africa fall into three major racial groups. These are the Whites of European descent, the Coloured of mixed descent and the Blacks who are members of the indigenous African tribes such as the Xhosas, Zulus and Tswanas. There is therefore a wide spectrum of skin pigmentation in these patients, ranging from the fair skins of the Whites through the generally brown skins of the Coloureds to the dark skins of the Blacks.

In view of the known predisposition to keloid formation in dark-skinned races it has been thought of value to assess whether ectopic bone formation is more common in Coloured and Native paraplegic patients than in their White counterparts.

Keloids are more common by far in the Negroes with the Hindus, Malayans and other Coloured races also showing a marked predisposition (Koonin, I964). In South Africa, the Natives have a far greater incidence of keloid formation than the Whites (Allan \& Keen, I954). Seventy-four per cent of 247 patients suffering from keloid formation reviewed by Cosman et al. (I96I) were found to be Negroes. Keloids are defined as benign, proliferative, fibrous outgrowths which macroscopically appear as a type of hypertrophic scar with a rounded, shiny surface often having a bizarre shape.

Spinal Injury Units in South Africa are unique as regards the high incidence of stab wound tetraplegia and paraplegia. Stab wounds into the spinal cord are rarely recorded in the large Spinal Injury Units in other countries and are a reflection of the high rate of stab wounds seen in the numerous assault cases dealt with throughout the country. 
Hardy and Dickson (1963) and Wharton and Morgan (I970) have analysed large series of patients with ectopic bone formation, but these authors have not considered the above-mentioned factors of racial incidence and stab wound paraplegia and therefore analysis of a series of our cases is thought to be of some value.

\section{Material and Method}

The X-rays of 317 patients all suffering from post-traumatic tetraplegia or paraplegia have been analysed. The cases were unselected and sequentially studied as the X-rays became available. The duration of paralysis varied from 3 months to over Io years.

All patients seen in this Unit have initial micturating cysto-urethrograms 3 months after admission and then annually for the rest of their lives. The control $\mathrm{X}$-ray of the pelvis is therefore examined for any evidence of ectopic bone formation. Specific X-rays of the upper limbs and knees were only obtained where clinically indicated.

\section{Results}

\section{Incidence of Ectopic Bone Formation}

Sixty-two (I9.6 per cent) of the 317 cases examined were found to have ectopic bone formation. Of these 62 cases 25 showed bilateral ectopic bone formation in the soft tissues around the hip joints while 36 cases showed only unilateral involvement.

\section{Racial Incidence}

Analysis of the incidence of ectopic bone formation in relation to the different racial groups as shown in Table I demonstrates that there is no significant difference in the incidence of ectopic bone formation in the three racial groups studied. There is close correlation between the number of cases studied in each racial group and the number of cases showing ectopic bone formation.

\section{Incidence in Relation to Sex}

Two hundred and seventy ( 85 per cent) of the patients examined were male patients while 47 ( 15 per cent) were female patients. Of the 62 patients who showed ectopic bone formation 57 ( 92 per cent) were males and 5 ( 8 per cent) feniales.

\section{TABLE I}

Incidence of ectopic bone formation in $3 \mathrm{i} 7$ post-traumatic paraplegic patients of different racial groups

\begin{tabular}{lcccc}
\hline Race & $\begin{array}{c}\text { No. of patients } \\
\text { X-rayed }\end{array}$ & $\begin{array}{c}\text { \% of total no. } \\
\text { of patients } \\
\text { X-rayed }\end{array}$ & $\begin{array}{c}\text { No. of patients } \\
\text { with ectopic } \\
\text { bone formation }\end{array}$ & $\begin{array}{c}\% \text { of total no. of } \\
\text { patients with } \\
\text { ectopic bone } \\
\text { formation }\end{array}$ \\
\hline White & 36 & II $\cdot 3$ & 6 & $9 \cdot 6$ \\
Coloured & 196 & $6 \mathrm{I} \cdot 8$ & 38 & $6 \mathrm{I} \cdot 2$ \\
Black & 85 & $26 \cdot 9$ & 18 & $29 \cdot 2$ \\
\hline
\end{tabular}


Relationship of Ectopic Bone Formation to Level of Spinal Cord Injury

Thirty-nine per cent of the cases examined had injury of the cervical spinal cord and were therefore tetraplegic while the remaining 6I per cent has sustained injury to the thoracic or lumbar spinal cord and were consequently paraplegic.

32.5 per cent of the cases who showed ectopic bone formation were tetraplegic patients while the remaining 67.5 per cent were paraplegic patients. There was therefore no particular difference in the incidence of ectopic bone formation in tetraplegics as opposed to paraplegics.

\section{Relationship of Ectopic Bone Formation to Degree of Paralysis}

$6 \mathrm{I} \cdot 5$ per cent of the 317 cases examined had complete motor and sensory loss below the level of injury, but a significantly higher proportion $(8 \mathrm{I} \cdot 3$ per cent $)$ of the cases who showed ectopic bone formation had complete paralysis. 38.5 per cent of the cases examined had only incomplete paralysis and only 18.6 per cent of the patients who showed ectopic bone formation were incomplete lesions.

\section{Ectopic Bone Formation following on Stab Wounds into Spinal Cord}

Fifty-six (18.5 per cent) of the 317 cases examined had sustained paralysis following on a stab into the spinal cord. Of these 56 cases only six cases (10.6 per cent) showed ectopic bone formation and is probably a reflection of the fact that the maiority of stab wounds into the spinal cord result in incomplete paralysis and as has been described above the incidence of ectopic bone formation would appear to be less in those cases with incomplete paralysis as compared to those showing complete paralysis.

\section{Clinical Features}

In the majority of cases clinical signs of ectopic bone formation are only noted when the condition is advanced and the patients are generally asymptomatic. The period of onset after spinal cord injury is variable, Hardy and Dickson (1963) have recorded a case in which ossification occurred I9 days after injury, but several years may lapse before the onset of this condition. The diagnosis is usually made as an incidental finding on X-raying the patient for other reasons. Ideally if all patients were repeatedly X-rayed at short intervals after injury the diagnosis of the onset of the condition would be made earlier. If, however, a large number of acute spinal injuries are present at any one time this procedure becomes time consuming bearing in mind that the majority of patients are immobilised often with skeletal traction for 12 weeks and therefore all the X-ray examinations must be performed as mobile examinations. Hardy and Dickson (1963) observe that extensive ectopic bone formation was often preceded by palpable soft tissue swelling of the thigh while Wharton and Morgan (I970) noted similar changes and pointed out that swelling of the thigh may be misdiagnosed as thrombo-phlebitis or cellulitis.

At this early stage $\mathrm{X}$-rays are negative and several cases in our Unit have also been misdiagnosed as thrombo-phlebitis.

Both Hardy and Wharton state that the blood chemistry is usually normal and that laboratory tests are therefore of little value in the early diagnosis of this condition. Nicholas (1973), however, in studying 22 patients demonstrates that the serum alkaline phosphatase is elevated in those patients with ectopic bone formation. This elevation occurred coincidentally with the swelling of the thigh and therefore is of use in differentiating early ectopic bone formation from thrombo-phlebitis, septic arthritis and cellulitis in those cases where X-ray findings 
are negative. Similar elevations of serum alkaline phosphatase coincident with ectopic bone formation were reported by Furman et al. (1970).

\section{Discussion}

The overall incidence of ectopic bone formation in this series is 19.6 per cent while the incidence in the literature is variously reported as from 4 to 49 per cent of patients having spinal cord injury (Miller \& O'Neill, 1949). This incidence, however, compares well with the incidence in two large series: Hardy and Dickson reporting a 16 per cent incidence and Wharton and Morgan a 20 per cent incidence.

There does not seem to be any relationship between ectopic bone formation and the degree of skin pigmentation of the patient, Native and Coloured patients showing no higher incidence than Whites.

The cause for the increased predisposition of black races to keloid formation is still unknown and one of the theories advanced, but not generally accepted, is that black races have a fibro-plastic predisposition. This apparently is also thought to include an increased tendency to form fibroids and adhesions (Asboe-Hansen, I960; Nason, I942).

There does not appear to be any significant relationship between the sex of the patient and incidence of ectopic bone formation. A slightly higher incidence in male patients is however noted.

Both Abrahamson and Kamberg (1949) and Hardy and Dickson (1963) found no relationship between the level of paralysis and the incidence of ectopic bone formation. Similar findings are present in our series where no relationship between the level of injury and ectopic bone formation is revealed. It is, however, noted that a significantly higher proportion of those patients with complete motor and sensory paralysis below the level of injury showed ectopic bone formation, but the cause for this finding is not evident.

The relatively lower incidence of ectopic bone fomation in stab wound paraplegia is probably a reflection upon the fact that the majority of these cases are incomplete spinal cord injuries and as has been described above the incidence of ectopic bone formation in the incompletely paralysed patient appears to be significantly lower than that found in completely paralysed patients.

\section{Conclusions}

I. There is no higher incidence of ectopic bone formation in dark-skinned (Native and Coloured) paraplegics than in White patients.

2. There does not appear to be any significant relationship between the sex of the patient and level of spinal cord injury and incidence of ectopic bone formation.

3. There is a significantly higher incidence of ectopic bone formation in patients with complete paralysis below the level of the lesion than in those patients with incomplete paralysis below the level of the lesion.

4. In those patients with paraplegia consequent upon stab-wounds into the spinal cord there is a lower incidence of ectopic bone formation than that due to other traumatic aetiology. This is thought to be due to the fact that stab-wounds into the spinal cord usually result in incomplete paralysis and as shown above patients with incomplete paralysis would appear to have a lower incidence of ectopic bone formation.

$$
\text { I } 4 / 3-C
$$




\section{SUMMARY}

The X-rays of 317 patients of different racial groups suffering from traumatic paraplegia have been examined for the presence of ectopic bone formation. Analysis of the results demonstrates that there is no higher incidence of ectopic bone formation in dark-skinned patients although it is well documented that there is an increased predisposition for keloid formation in dark-skinned races. There is a significantly higher incidence of ectopic bone formation in complete paraplegia as opposed to incomplete, but there is no relationship to sex, nor to the level of the lesion. Patients with stab-wound paraplegia were shown to have a lower incidence of ectopic bone formation as compared to paraplegia due to other causes.

\section{RÉSUMÉ}

Les radiographies de 317 malades de differentes groupes raciaux souffrant de paraplegie traumatique ont été examinée pour le présence de ostéomes os formation. Analyse de les résultates demontres que ný a pas plus de cas ostépmes os formation en malades de peaus-sombre bien que le bien documenté qúil ya une augmentation dans la predisposition de cheloid formation en races de peaus sombre. Il ya une augmentation significatif dans la formation de ostéomes chez le paraplegique partial, mais n'y a pas de rapport arec le sexe ni le niveau de la lésion. Les malades arec coup de poignard paraplegie a révèl mois d'incidence d'ostéomes, os formation, que les comparable a paraplegie dû a autre causes.

\section{ZUSAMMENFASSUNG}

Die Röntgenbilder von 317 Patienten verschiedener Rassengruppen, die an traumatischen Querschnittslähmungen leiden, sind auf das Vorhandensein von heterotopischer Ossifikation untersucht worden. Die Auswertung der Ergebnisse zeigt, dass heterotopische Ossifikation bei dunkelhäutigen Patienten nicht vermehrt vorkommt, obwohl eine erhöhte Praedisposition für Keloidbildung in dunkelhäutigen Rassen wohlbekant ist. Es zeigt sich ein auffallend höheres Vorkommen von heterotopischer Ossifikation bei den kompletten Querschnittslähmungen im Gegensatz zu den inkompletten, jedoch unabhängig von Geschlecht oder der Höhe der Verletzung. Patienten mit Querschnittslähmungen verursacht durch Messerstiche, scheinen ein vermindertes Vorkommen von heterotopischer Ossifikation zu haben im Vergleich zu Querschnittsgelähmten, deren Lähmungen durch andere Ursachen hervorgerufen worden sind.

\section{REFERENCES}

Abrahamson, D. J. \& Kamberg, S. (1949). Spondylitis, pathological ossification and calcification associated with spinal cord injury. F. Bone E Foint Surgery, 3I-A, 275.

Allan, J. C. \& Keen, P. (1954). Keloids and the South African Bantu. South African Medical fournal, 28, 1034 .

Asboe-Hansen, G. (I960). Hypertrophic scars and keloids. Dermatologica (Basel), I20, I78.

Cosman, B., Crikelair, G. F., Gaulin, J. C. \& Laffer, R. (I96i). Surgical treatment of keloids. Plast. Reconstr. Surg. $27,335$.

Furman, R., Nicholas, J. J. \& Jivoff, L. (1970). Elevation of the serum alkaline phosphatase coincident with ectopic bone formation in paraplegic patients. F. Bone $\mathbb{E}$ foint Surgery, 52-A, II3I.

HARDY, A. G. \& DICKSON, J. W. (1963). Pathological ossification in traumatic paraplegia. 7. Bone \& foint Surgery, 45-B, 76 .

Koonin, A. J. C. (I964). The aetiology of keloids. South African Med. Fournal, 38, 913.

Miller, L. F., \& O’Neill, C. J. (1949). Myositis ossificans in paraplegics. F. Bone $\mathcal{E}$ Foint Surgery, 31-A, 283.

Nason, L. H. (I942). Keloids and their treatment. New Engl. F. Med. 226, 883.

Nicholas, J. J. (I973). Ectopic bone formation in patients with spinal cord injury. Arch. Phys. Med. Rehabil. 54, 354.

Wharton, W. G. \& Morgan, T. H. (1970). Ankylosis in paralysed patients. F. Bone E foint Surgery, 52-A, I05. 